\title{
A DEATH FROM INOCULATED SMALLPOX IN THE ENGLISH ROYAL FAMILY
}

\author{
by
}

\section{DERRICK BAXBY*}

ATTENTION has often been drawn to cases of naturally-acquired smallpox in the English Royal Family. ${ }^{1}$ However, the death in 1783 of an English Prince from inoculated smallpox has been neglected by medical historians. An analysis of the circumstances is presented here. The principal source of information was a member of the Royal Household, Charlotte Papendiek, whose personal experience of smallpox is also worth recording.

\section{THE DEATH OF PRINCE OCTAVIUS}

Octavius, the eighth son and thirteenth child of George III and Queen Charlotte, was born in 1779. Although there are no detailed records of his death in the Royal Archives, he died in 1783, a few days after being inoculated with smallpox virus. The notice of his death in the Annual Register ${ }^{2}$ states simply "May 3d, Prince Octavius, at Kew Palace, of inoculation for the smallpox, aged four years two months and ten days." More information was provided by Charlotte Papendiek, ${ }^{3}$ whose husband was page to the Princess Royal at the time (see below).

Octavius was inoculated along with Princess Sophia, the twelfth royal child. They were taken to Kew to be under the care of Sergeant-Surgeon Pennell Hawkins, who was living with the Papendieks, ${ }^{4}$ and Princess Sophia recovered without mishap. Octavius, however, "was supposed to have caught cold just when the eruption should have come out" and he died "from suffocation which nothing could relieve."

Many accounts of George III and his family make no mention of the cause of Octavius's death, but two do mention that his death was due to "vaccination". ${ }^{6}$ The failure of two others to mention the cause of death is perhaps surprising. Watson

*Derrick Baxby, BSc, PhD, Department of Medical Microbiology, University of Liverpool, Liverpool L69 3BX.

'See for example 'Jenner centenary number', Br. med. J., 1896, i: 1263; C. W. Dixon. Smallpox, London, Churchill, 1962, pp. 191-195; D. R. Hopkins, Princes and peasants: smallpox in history, University of Chicago Press, 1983.

2'Deaths', Ann. Reg., 1783, p. 238.

${ }^{3}$ Charlotte Papendiek, Court and private life in the time of Queen Charlotte: the journals of Mrs Papendiek, (edited by V. D. Broughton), 2 vols., London, Richard Bentley, 1887.

4 Ibid., vol. 1, p. 270. Pennel Hawkins was the brother of the more famous Caesar Hawkins.

'Ibid., vol. 1, pp. 270-271.

- D. Duff, Edward of Kent, London, Stanley Paul, 1938, p. 49. Nesta Pain, George III at home, London, Eyre Methuen, 1975, p. 40. It is important to distinguish between "inoculation" (later termed variolation), the deliberate infection with smallpox virus, and "vaccination", infection with an immunologically-related poxvirus from animals. See, e.g., D. Baxby, Jenner's smallpox vaccine, London, Heinemann Educational Books, 1981. 


\section{Derrick Baxby}

briefly discussed smallpox inoculation and mentioned the inoculation of George III. ${ }^{7}$ Olwen Hedley described the inoculation of George, Prince of Wales, and Frederick, Duke of York, and quoted from Charlotte Papendiek's journals. She also quoted the letter written by Queen Charlotte to Lady Pembroke which mentions the death of Octavius. "Twice have I felt what you do feel, the last time without the least preparation for such a stroke, for in less than eight and forty hours was my son Octavius, in perfect health, sick and struck with death immediately.",

Unfortunately, these brief accounts pose questions for which no answers have been found. For example, how long after the inoculation of Octavius did his symptoms start? How did the progress of his inoculation compare with that of Princess Sophia, who recovered? Was there a likely source for the "cold" Octavius may have caught? Despite these unanswered questions, the accounts which are available provide three points of interest.

First is the significance to be attached to the information that Octavius was "in perfect health" just before his death. Queen Charlotte's letter, written in July 1784, was a letter of condolence on the death of one of Lady Pembroke's children, and it is possible that she simply wished to indicate that her family too had experienced sudden death. It seems unlikely that Octavius would have been in perfect health just before the eruption appeared. The so-called "eruptive fever" was a common occurrence in inoculated patients. Dimsdale described it as "slight remitting pains in the head and back succeeded by transient shiverings and alternate heats." 10 Chandler wrote, "From the seventh day to the ninth or tenth day I expect my patients to begin to complain a little ... in a day or two from their first beginning to complain the pustules seldom fail to appear."' So we could expect Octavius to have felt the early effects of the eruptive fever in the period before his death.

Second is the difficulty of trying to assess the significance of the cold Octavius is supposed to have caught. Respiratory symptoms such as tracheitis, laryngitis, and even bronchitis and pneumonia, which were common features of naturally-acquired smallpox, could occur during the pre-eruptive phase,,$^{12}$ and probably occurred in some inoculated patients. Also, animals naturally infected with the related cowpox virus sometimes die with respiratory signs before skin lesions develop. ${ }^{13}$ Whatever the precise relationship between Octavius's cold and the inoculation, it is reasonable to conclude that he would not have died if he had not been inoculated.

The third point of interest is that Queen Charlotte professed to being unprepared for Octavius's death. This is difficult to believe, because inoculation was always attended by risk. Although the mortality from inoculation varied, authorities such as

\footnotetext{
'J. S. Watson, The reign of George III, Oxford, Clarendon Press, 1960, p. 11.

- Olwen Hedley, Queen Charlotte, London, Murray, 1975, pp. 99, 126-127.

- Lord Herbert (editor), Pembroke papers, London, Cape, 1950, p. 259.

${ }^{10} \mathrm{~T}$. Dimsdale, The present method of inoculating for the smallpox, 5th ed., London, Owen, 1769, pp. 31-32.

11 B. Chandler, An essay towards an investigation of the present successful and most general method of inoculation, London, Wilkie, 1767, pp. 32-33.

12 A. R. Rao, Smallpox, Bombay, Kothari Book Depot, 1972, pp. 14, 30. Dixon, op. cit., note 1 above, pp. 93-94.

${ }^{13}$ D. Baxby, D. G. Ashton, D. Jones, L. R. Thomsett, and E. M. Denham, 'Cowpox virus infections in unusual hosts', Vet. Rec., 1979, 109: 175.
} 


\section{A death from inoculated smallpox in the English Royal Family}

Robert Willan, George Pearson, and James Moore were to estimate the overall mortality as 1 in $200 .{ }^{14}$ So the Queen should have been warned, or should even have known herself, of the possible dangers. Although we know that Octavius was attended by Pennell Hawkins after the inoculation, we do not know who performed it; Creighton implies that it was William Bromfield.15 However, Bromfield had apparently lost the Queen's confidence earlier, when his inoculation of Charlotte Papendiek failed to protect her from smallpox (see below).

The dangers of inoculation were always of concern, and when the safe alternative of vaccination was introduced in 1798 by Edward Jenner, the earlier death of a royal prince from inoculation would have made excellent propaganda for those promoting the new procedure. However, the major figures involved in the introduction of vaccination apparently made no use of it. It is unlikely that they did not know of it, and the reason may well have been the unstable mental state of George III, ${ }^{16}$ and the fact that royal patronage would be needed to ensure acceptance of vaccination. ${ }^{17}$ Although Octavius would undoubtedly have survived if vaccination had been available in 1783, it might well have been thought unwise to refer to Octavius at all, in case it provoked an unfavourable outburst from the King. Also, despite some suggestions throughout the nineteenth century that vaccination could transmit syphilis, ${ }^{18}$ the safety of vaccination was soon appreciated. Consequently, if the example of Octavius was to be used, it would only have been of value in the early days of the vaccination campaign.

Many books dealing with smallpox have been consulted, but only two have been found which mention the death of Prince Octavius. In 1809, Richard Pew, a physician of Sherborne, Dorset, published a pamphlet which supported Jennerian vaccination; as such it was one of many. However, in the introduction which discussed the dangers of inoculated smallpox, Pew wrote, "And at no very remote period (May the 3d 1783) a Prince of the blood-royal of England (Prince Octavius) was killed by the inoculated smallpox."19 It is unlikely that Pew was the only person to mention Octavius in this early period. However, the more times the incident was mentioned, the more likely it is that later writers would have noticed it. This has not happened. Indeed, the writer of a recent and very well-researched history of smallpox ${ }^{20}$ has found no further mention of Octavius's death, beyond Charles Creighton, whose citation of Mrs Papendiek alone reinforces the belief that the incident had been ignored by most medical writers. ${ }^{21}$

\section{THE INOCULATION OF MRS PAPENDIEK}

It was the effectiveness of vaccination, rather than its safety, which was to be

14 Baxby, op. cit., note 6 above, p. 27.

is C. Creighton, $A$ history of epidemics in Britain, 2nd ed., London, Cass, 1965, vol. 2, p. 515. Creighton misspells the name as "Bromfeild".

16 Ida Macalpine and R. Hunter, George III and the mad-business, London, Penguin Press, 1969.

17 The second edition of Jenner's Inquiry was dedicated to the King, and members of the Royal Family were patrons of the Royal Jennerian Society.

18 C. Creighton, The natural history of cowpox and vaccinial syphilis, London, Cassell, 1887.

$19 \mathrm{R}$. Pew, Observations on an eruptive disease which has lately occurred in the town of Sherborne, Dorset, after vaccination, Sherborne, Langdon, 1809, p. 9.

20 Hopkins, op. cit., note 1 above, and personal communication.

${ }^{21}$ C. Creighton, Jenner and vaccination, London, Sonnenschein, 1889, p. 141. 


\section{Derrick Baxby}

questioned as cases of smallpox occurred in individuals who had been vaccinated a few years earlier. In an attempt to minimize the significance of these failures, attention was drawn to cases of smallpox in people who had earlier been inoculated. ${ }^{22}$ In a letter to James Moore, Jenner mentioned that his friend John Ring had collected seventeen such cases from among the nobility, and that Queen Charlotte's surgeon Bromfield abandoned inoculation because of failures "one with a portion of the same thread as was used on the Duke of Clarence and Prince Ernest, the Queen's brother." ${ }^{23}$ Creighton later briefly referred to this incident. ${ }^{24}$ The individual in question was Charlotte Louise Henrietta Albert, later Mrs Papendiek. Frederick Albert had been page of the back stairs to the Queen since 1761, and his daughter, born in 1765, had been brought up in the Royal Household. ${ }^{25}$

She was inoculated along with the two royal princes in 1769. She was two and a half years old, and so her account must have been based on the recollections of friends and relatives. However, there is no reason to doubt its veracity. The inoculation was done "... after this manner: two punctures in the arm near to each other were made with the point of a lancet, through which a thread was drawn several times under the skin, and this on both arms." Charlotte described an apparently successful take on herself and Prince William, but on "Prince Ernest it took no effect whatever." ${ }^{26}$ Nevertheless, they were all assured by Bromfield that they "were secure from further fear of disease".

In November 1775, Charlotte's brother developed smallpox and Bromfield, on being consulted, stated that her inoculation in 1769 would protect her. It did not.

I was worse than my dear little brother, and for six weeks at least suffered the martyrdom of that dreadful disease. I had my good Brighton nurse, but no one could give me any comfort or alleviate pain. I could only be lifted by four people, one at each corner of the sheet, to have my bed made; for not a pin's point could be placed between the pustules. Then all my beauty was gone, which before my father was flattered by. I was lost to all the fond hopes in which he had indulged. ${ }^{27}$

Evidentally, Charlotte's infection was severe despite the inoculation seven years earlier, and we can sympathize with her over the loss of her beauty. The Queen was also concerned, but for a different reason. She was worried that the two princes, inoculated at the same time as Charlotte, might not be protected. Bromfield apparently told the Queen that Charlotte had been inoculated with material from a different donor and that all would be well with the princes. ${ }^{28}$ According to Jenner, who wrote many years later and did not cite his source, Bromfield used the same thread on all three patients. ${ }^{29}$ In any event, Bromfield lost the Queen's confidence. Indeed, in

\footnotetext{
${ }^{22}$ See, for example, National Vaccine Establishment, Report of the case of the Hon. Robert Grosvenor, London, 1811.

${ }^{23} \mathrm{~J}$. Baron, The life of Edward Jenner, London, Colborn, 1838, vol. 2, pp. 400-401. Letter dated 10 March 1817.

${ }^{24}$ Creighton, op. cit., note 15 above.

${ }^{2 s}$ Royal Archives, Windsor Castle, see also Papendiek, op. cit., note 3 above.

26 Papendiek, op. cit., note 3 above, vol. 1, pp. 41-42.

27 Ibid., p. 71.

28 Ibid. The published version refers incorrectly to "Blomfield".

29 Letter to James Moore, Baron, op. cit., note 23 above. Jenner wrote, "Is this not a precious anecdote for your new work?" Moore had recently published his History of smallpox (London, Longmans, 1815). The new work was presumably his History of vaccination (London, Callow, 1817), which, however, contains no reference to the incident.
} 


\section{A death from inoculated smallpox in the English Royal Family}

view of the fact that the inoculation of Prince Ernest "took no effect whatever", it is perhaps a little surprising that Bromfield was able to convince the Queen that it had been successful.

It is of interest that Queen Charlotte lost confidence in Bromfield but not in inoculation as a method of preventing smallpox. This led inevitably to the inoculation and tragic death of Prince Octavius, an event unfortunately neglected by medical historians.

\section{ACKNOWLEDGEMENTS}

Information from the Royal Archives is published with the gracious permission of Her Majesty the Queen.

I would like to thank Jane Langton, Royal Archivist who answered many queries, Dr Hugh Torrens for bringing my attention to the pamphlet by Pew, and Dr Donald R. Hopkins for many interesting discussions. 